\title{
Pemanfaatan Facebook Ads Untuk meningkatkan Brand Awareness pada Produk Lokal
}

\author{
Gita Aprinta E.B \\ (gita@usm.ac.id) \\ (Pengajar Jurusan Ilmu Komunikasi Universitas Semarang)
}

\begin{abstract}
Abstrak
Facebook ads is the most recent feature ad in facebook. Its simply stated as paid advertisment to help products in increasing their brand awareness. The objective is to optimazing brands who want to reach thousands of costumers, by maximzing promotion through facebook ads. Brand awareness is quite important for costumer to help them recalling brand, doing the purchasing, and have loyal to specific brand. Facebook ads providing huge opportunity for each costumer to know, recall, involve and participate in sharing information to other social media users.
\end{abstract}

Keywords: Brand Awareness, Facebook Ads, Social Media

\section{Pendahuluan}

Perkembangan teknologi dan komunikasi, membawa perubahan terhadap berbagai kebutuhan manusia. Salah satunya adalah akses terhadap media, yang makin hari bergeser menjadi sebuah kebutuhan primer individu. Thomas L. Friedman mengatakan bahwa dunia semakin rata dan setiap orang dapat mengakses apapun dari sumber manapun (Nasrulloh, 2015: 1). Kehadiran media baru mempertegas kebutuhan tersebut karena membuat informasi menjadi terbuka, mudah dicari, dan mudah didapatkan.

Salah satu fitur media baru adalah keberadaan media sosial, yang sejak kelahirannya, menjadi cerita baru bagi berbagai bidang. Van Dijk (2003) mendefinisikan media sosial sebagai platform media yang memfokuskan pada eksistensi pengguna yang memfasilitasi mereka dalam beraktivitas maupun berkolaborasi. Sehingga, media sosial dapat dilihat sebagai fasilitator online yang menguatkan hubungan antarpengguna sekaligus sebuah ikatan sosial (Nasrulloh, 2015: 11). Pada perkembangannya media sosial tidak lagi sekedar digunakan untuk menjalin relasi secara online namun juga kepentingan bisnis, terutama untuk kepentingan pemasaran. Kehadiran media sosial dalam pemasaran dapat dilihat dari dua sisi, yakni sisi pengiklan dan sisi pengguna media sosial. Media sosial menawarkan konten yang beragam mulai dari teks, visual, sampai audio-visual. Salah satu media sosial yang melaksanakan praktik iklan adalah Facebook.

Facebook merupakan salah satu platform media sosial yang memiliki nilai tinggi dalam dunia komunikasi pemasaran. Memiliki pengguna lebih dari 1,2 trilliun yang tersebar di berbagai negara, facebok menawarkan akses langsung kepada konsumen(http://thenextweb.com/faceboo k/2013/10/30/facebook-passes-1-19billionmonthly-active-users-874-million-mobileusers-728-million-daily-users/, diakses tanggal 13 April 2016, pukul 13.23). Hal inilah yang menjadikan facebook sebagai sebuah platform yang cukup compatible untuk digunakan oleh para pemasar, khususnya pemasar produk lokal untuk meningkatkan merek produk mereka kepada masyarakat. Menggunakan facebook untuk meningkatkan kesadaran terhadap merek produk lokal bukan persoalan mudah, mengingat pemasar harus memahami bagaimana cara bekerja platform tersebut sebagaimana konsumen menggunakannya.

Facebook memperkenalkan sebuah fitur yang disebut sebagai Facebook Ads atau iklan facebook. Dalam merencanakan 
iklan, pemasar atau pengiklan dapat dengan spesifik mengatur taget pasar yang dituju, seperti wilayah geografi, jenis kelamin, usia, pendidikan, dan lain sebagainya, sehingga membuat iklan yang dibuat menjadi lebih efektif. (http://www.socialadstool.com/facebookads-guide/how-facebook-ads-work/, diakses tanggal 13 April 2016, pukul 19.46). Oleh sebab itu facebook ads diangap sebagai sebuah wadah yang tepat untuk membantu produk lokal dalam meningkatkan brand awareness produk mereka.

\section{Pembahasan}

\section{Brand Awareness dan Produk Lokal}

Sebuah produk dapat dikategorikan sebagai produk lokal apabila produk tersebut memenuhi ketentuan sebagai berikut; (1) produk terbuat dari bahan yang berasal dari dalam negeri; (2) tenaga kerjanya berasal dari dalam negeri; (3) produk tersebut menggunakan merk lokal; (4) kepemilikan usaha.

Pada dasarnya, dalam pemasaran, sebuah produk, baik itu produk lokal maupun tidak, memerlukan sebuah strategi komunikasi yang bertujuan untuk mengenalkan produk kepada masyarakat yang menjadi target sasarannya. Strategi komunikasi ini disebut sebagai strategi komunikasi pemasaran. Komunikasi pemasaran didefinisikan oleh Kotler sebagai sebuah proses perencanaan dan menjalankan konsep, harga, promosi, serta distribusi sejumlah barang dan jasa untuk menciptakan pertukaran yang mampu memuaskan tujuan individu dan organisasi. (Kotler \& Keller; 2009: 172)

Tujuan komunikasi pemasaran sendiri terdiri dari tiga tahap perubahan. Tahap pertama disebut tahap perubahan pengetahuan, di mana pada tahapan ini, melalui komunikasi pemasaran yang dijalankan, konsumen atau masyarakat mengetahui tahapan keberadaan sebuah produk, untuk apa produk diciptakan, dan ditujukan kepada siapa.

Dalam tahapan ini konsumen diharapkan sampai pada tahapan untuk memiliki daya ingat terhadap sebuah produk atau yang sering disebut sebagai brand awareness. Sebuah produk khususnya produk lokal ketika diperkenalkan kepada masyarakat diharapan mempunyai sebuah pembeda untuk dapat dikenal dan diingat lebih dalam oleh calon konsumen dibandingkan merek produk yang lain.

Kemampuan konsumen untuk mengingat produk dibagi menjadi beberapa tingkatan sebagaimana diungkapkan oleh Aaker, yaitu (Shimp, 2010: 37-38):

\section{a. Brand Recognition}

Atau yang disebut juga sebagai tingkatan pengenalan terhadap sebuah produk yang merupakan tingkatan paling dasar. Meskipun merupakan tingkatan minimal, namun merupakan tahapan yang cukup penting dari kesadaran merk.

b. Brand Recall

Pada tingkatan ini, konsumen diharapkan dapat mengingat kembali merk tertentu tanpa bantuan. Artinya bahwa konsumen mempunyai ingatan terhadap sebuah merek yang mereka simpan dalam benaknya.

c. Top of Mind

Konsumen tidak lagi perlu diingatkan untuk mengenal sebuah merk . Sebuah merk sudah mendominasi pikiran konsumen, dan ketika menyebut sebuah produk otomatis konsumen hanya akan memikirkan dan menyebut satu merk.

Brand awareness menjadi patokan tersendiri bagi sebuah merk untuk mengukur efektivitas kegiatan komunikasi pemasaran yang dilakukan oleh perusahaan. Bagi sebuah produk lokal, membentuk dan meningkatkan kesadaran merk kosumen merupakan pekerjaan rumah harus dilakukan agar, produk yang dimiliki tidak hanya dapat dikenal namun juga menjadi puncak ingatan calon konsumen dan konsumen. Media sosial 
menjadi pilihan tepat, mengingat bahwa perkembangan arus sosial yang cukup pesat, memaksa sebuah merk untuk dapat berbagi, berkomunikasi, dan membicarakannya secara terus menerus dalam media yang cukup massive.

\section{Facebook Ads dan Brand Awareness}

Kampanye kesadaran merek merupakan hal penting yang perlu dilakukan oleh sebuah produk untuk meningkatkan kesadaran merek para konsumen. Facebook mengenalkan sebuah fitur baru yang bernama Facebook Ads atau iklan Facebook berbayar. Cara kerja Facebook ads adalah melakukan optimalisasi kesadaran merk dengan membantu pengiklan untuk menemukan konsumen dalam mengingat kembali keberadaan sebuah merek, sebagaimana yang terlihat dalam gambar di bawah ini:

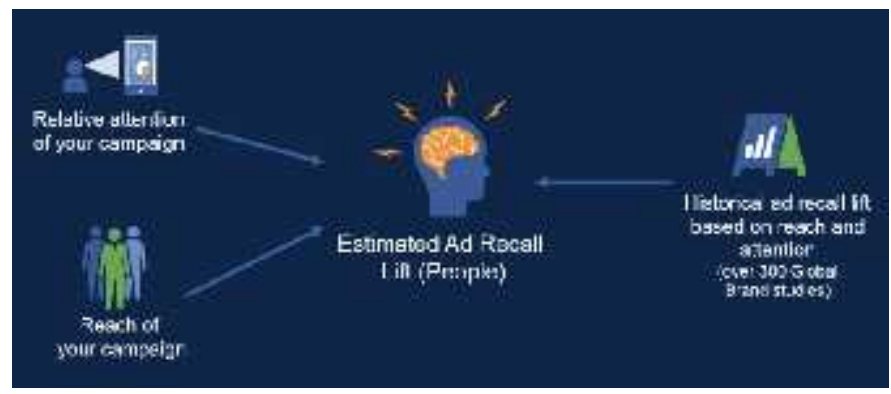

Gambar 1. Kampanye Kesadaran Merek Sumber:

https://developers.facebook.com/ads/b $\log /$ post/2015/12/09/brand-awareness/ diakses tanggal 15 April, pukul 10:13

Ada beberapa hal yang perlu diperhatikan untuk dapat memanfaatkan facebook ads dengan tepat, yaitu:

1. Tentukan budget atau biaya iklan yang dikehendaki. Facebook menyediakan pilihan beberapa mata uang yang akan digunakan, salah satunya adalah rupiah

2. Pilih jadwal untuk melakukan kampanye kesadaran merek. Jadwal ini meliputi tanggal dimulainya kampanye, jam, dan tanggal berakhir.
3. Pilih khalayak yang menjadi sasaran sebagai calon konsumen merek produk. Target konsumen bisa dipilih berdasarkan lokasi, usia, jenis kelamin, ketertarikan, dan lain-lain.

Pemanfaatan facebook ads bertujuan untuk meningkatkan jumlah calon konsumen yang mengingat merek sebuah produk setelah produk tersebut diiklankan. Estimasi calon konsumen dapat mengingat sebuah merek adalah dalam waktu kurang lebih 2 hari setelah mereka melihat kampanye merek tersebut diluncurkan di facebook. (http://mutesix.com/how-toleverage-facebooks-new-brand-awarenessads/, diakses tanggal 15 April 2016, jam $12: 24)$

Untuk dapat melakukan kampanye merek melalui facebook ads, produk pengiklan harus mempunyai merek yang cukup solid dan memahami cara kerja platform dengan baik. Kampanye merek yang dilakukan akan berdampak pada bukan hanya meningkatkan kesadaran merek, melainkan juga terjadinya percakapan yang memberikan keuntungan bagi perusahaan untuk meningkatkan kesadaran merek dan juga penjualan. (http://xen.com.au/use-facebook-increasebrand-awareness/, diakses tanggal 15 April, jam 12:27)

Ketika sebuah platform dipahami secara mendalam tentang bagaimana cara dan penggunaannya, maka platform tersebut akan memberikan hasil yang maksimal. Melakukan pembaruan secara reguler pada halaman facebook ads akan menstimulus calon konsumen untuk mengunjungi halaman tersebut sesering mungkin. Semakin sering calon konsumen atau target khalayak mengunjungi halaman facebook ads sebuah merek maka akan memberikan kemungkinan untuk mereka melakukan pembelian atau paling tidak berbagi informasi terkait merek tersebut dengan pengguna media sosial lainnya.

Sifat alami facebook yang memungkinkan pengguna untuk saling berbagi informasi. Dorongan inilah yang 
membuat seseorang merasa perlu berbagi informasi berharga akan sebuah kampanye merek yang dianggapnya menarik. Tanpa disadari, pembagian informasi yang dilakukan oleh para calon konsumen ke sesama pengguna facebook ini dapat meningkatkan kesadaran merek sampai dengan empat puluh persen. Melalui facebook ads juga, perusahaan dapat melakukan monitoring yang berhubungan dengan bagaimana sebuah merek dibicarakan diantara calon konsumen. Ketika sebuah merek dibicarakan di media sosial, perusahaan harus mulai peka untuk mengumpulkan informasi sehingga dapat melakukan berbagai macam inovasi agar membuat merek produk menjadi lebih menarik melalui strategi kampanye merek.

Dalam memanfaatkan media sosial untuk meningkatkan kesadaran merek produk lokal, khususnya pemanfaatan facebook ads, ada beberapa point yang harus dicapai (http://aksimaya.co.id, akses tanggal 15 April 2016, jam 13:06):

\section{Reach}

adalah mendapatkan sebanyak mungkin kepercayaan dari pelanggan. Kepercayan ini dilihat dari jumlah pengikut dari laman facebook merek tersebut. Selain jumlah follower, like, coment, sharing juga merupakan indikasi dalam menentukan jangkauan kepercayaan konsumen.

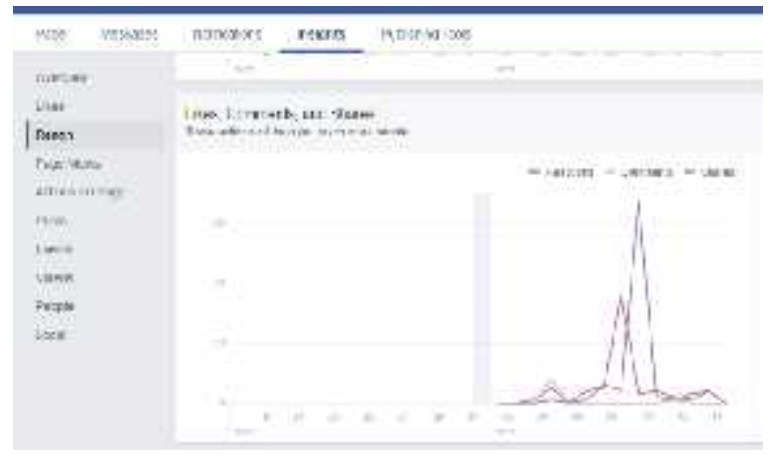

Gambar 2. Tabel Jangkauan Kepercayaan Sumber: http://facebook.com

\section{Traffic}

Atau lalu lintas kunjungan. Ada dua jenis traffic, direct traffic dan referral trafic. Untuk direct traffic konsumen akan langsung mengakses akun merek. Sedangkan untuk refferal traffic, konsumen akan mengakses merek kita dari tautan lain.

3. Khalayak baru atau Konsumen baru

Media sosial selalu mengalami perkembangan setiap harinya, oleh itu dibutuhkan inovasi untuk mencari formula yang tepat agar dapat menarik perhatian calon konsumen baru. Demikian juga dengan fitur facebook ads, ke depannya fitur facebook ads bisa dikembangkan dengan memanfaatkan potensi jangkauan yang lebih luas.

\section{Expertise}

Sebuah merek harus dapat mengeksplorasi citra kepada konsumennya. Caranya adalah menyediakan informasi yang bermutu, penting, dan memiliki kegunaan kepada konsumen. Facebook menyediakan laman unggah informasi yang dapat ditulis oleh perusahaan, kemudian menyebarluaskannya melalui fasilitas facebook ads dengan penjadwalan sesuai yang diinginkan.

\section{Penutup}

Facebook ads merupakan fasilitas baru yang disediakan oleh facebook untuk membantu produk agar dapat menjangkau kepercayaan calon konsumen dan konsumen mereka. Melalui kampanye iklan berbayar, sebuah merek dapat menentukan target khalayak dan optimalisasi fitur untuk dapat meningkatkan kesadaran merek calon konsumen dan konsumen. Kesadaran merek yang dimiliki oleh konsumen penting untuk dapat membantu konsumen dalam menentukan keputusan pembelian sampai pada tingkat loyalitas konsumen terhadap sebuah merek. Cara kerja facebook ads memberikan keleluasaan 
bagi para konsumen untuk melihat, terlibat, dan berpartisipasi terhadap penyebaran informasi kepada sesama pengguna media sosial.

\section{Daftar Pustaka}

Kotler, P., \& Keller, K. L. (2009). Marketing Management. Upper Saddle River, N.J: Pearson Prentice Hall. Chicago (Author-Date, 15th ed.).

Rulli Nasrulloh. (2015). Media Sosial; Perspektif Komunikasi, Budaya, dan Sosioteknologi. Simbiosa Rekatama Media. Bandung.

Shimp, Terrence A. (2010). Advertising, Promotion, and Other Aspects of Integrated Marketing Communicatons. South-Western Sumber Internet Cengage Learning. Mason, USA.

http://aksimaya.co.id, akses tanggal 15 April 2016, jam 13:06. http://thenextweb.com/facebook/2013/10/3 0/facebook-passes-1-19-billionmonthly-active-users-874-millionmobile-users-728-million-dailyusers/, diakses tanggal 13 April 2016, pukul 13.23.

http://www.socialadstool.com/facebookads-guide/how-facebook-adswork/, diakses tanggal 13 April 2016, pukul 19.46.

https://developers.facebook.com/ads/blog/ post/2015/12/09/brand-awareness/ diakses tanggal 15 April 2016, pukul 10:13.

http://mutesix.com/how-to-leveragefacebooks-new-brand-awarenessads/, diakses tanggal 15 April 2016, jam 12:24.

http://xen.com.au/use-facebook-increasebrand-awareness/, diakses tanggal 15 April, jam 12:27. 